\title{
PERANAN PEMERINTAH DAERAH DALAM MENGAWASI KELESTARIAN TERUMBU KARANG KABUPATEN WAKATOBI
}

\author{
La Hasi ${ }^{1}$, Rudi Hardi' ${ }^{1}$ Hamrun${ }^{1}$ \\ ${ }^{1}$ Program Studi Ilmu Pemerintahan Fakultas Ilmu Sosial dan Ilmu Politik \\ Universitas Muhammadiyah Makassar \\ Jl. Sultan Alauddin No. 259 Makassar 90221 \\ Telp. 0411-866972 ext.107.Fax.0411-8655888 \\ lahasi@yahoo.co.id, rudihardi@gmail.com hamrun07@gmail.com
}

\begin{abstract}
The purpose of this study was to determine the government's role in overseeing the conservation of coral reefs. This research is a qualitative research. Data collection techniques used were observation, interviews and documentation. The results showed that the government's role in overseeing the conservation of coral reefs in the Wakatobi has been accomplished. Factors that support is a strong commitment from local governments, communities, the central government and the institutions of society concerned with the preservation of coral reef resources. Factors that inhibit the lack of labor inspectors, inadequate infrastructure and inadequate budgets to carry out surveillance operations reef conservation.
\end{abstract}

Keywords : role, local government, coral reefs.

\begin{abstract}
ABSTRAK
Tujuan penelitian ini adalah untuk mengetahui peranan pemerintah daerah dalam mengawasi kelestarian terumbu karang. Jenis penelitian ini adalah penelitian kualitatif. Teknik pengumpulan data yang digunakan berupa observasi, wawancara dan dokumentasi. Hasil penelitian menunjukkan bahwa peranan pemerintah daerah dalam mengawasi kelestarian terumbu karang di Kabupaten Wakatobi telah terlaksana. Faktor yang mendukung yaitu adanya komitmen yang kuat dari pemerintah daerah, masyarakat, pemerintah pusat serta lembaga-lembaga masyarakat yang peduli terhadap pelestarian sumberdaya terumbu karang. Faktor yang menghambat yaitu kurangnya tenaga pengawas, sarana prasarana yang kurang memadai dan anggaran yang belum mencukupi untuk menjalankan operasi pengawasan pelestarian terumbu karang.
\end{abstract}

Kata Kunci : Peranan, Kelestarian,Terumbu, Karang. 


\section{A. PENDAHULUAN}

Indonesia merupakan
kepulauan terbesar di dunia, memiliki
sumberdaya alam hayati laut yang potensial
seperti sumberdaya terumbu karang. Berdasarkan hasil penelitian pada tahun 1998, luas terumbu karang Indonesia adalah 42.000 $\mathrm{km} 2$ atau $16,5 \%$ dari luasan terumbu karang dunia yaitu seluas $255.300 \mathrm{~km} 2$ dengan 70 genera dan 450 spesies (Soediono, 2008).

Terumbu karang merupakan sumber kehidupan bagi jutaan nelayan dan masyarakat, serta sumber devisa bagi negara. Ikan-ikan bernilai ekonomi tinggi yang selama ini ditangkap di daerah terumbu karang antara lain kerapu, kakap,napoleon, beronang, kuwe/siwi, ekor kuning, kembung, dan berbagai jenis ikan hias. Sementara biota nonikan ditangkap/diambil di daerah terumbu karang di antaranya; kima, kerang, kerangmutiara,susu bundar, teripang, rumput laut,bulu babi, lobster, sotong,dan sebagainya.

Jika kita mencermati secara seksama, hamparan terumbu karang yang terbentang di wilayah pesisir dan pulau-pulau kecil memiliki empat fungsi utama bagi kehidupan manusia, yaitu sebagai penyedia sumber daya alam; penyedia jasa pendukung kehidupan; ekosistem terumbu karang menyediakan obyek wisata dan rekreasi yang sangat indah dan mempesona; dan sebagai pelindung dari bencana alam, ekosistem terumbu karang mampu melindungi manusia dari berbagai bahaya alam yang terjadi di wilayah pesisir dan pulau-pulau kecil. Dengan ke empat fungsi utama ekosistem terumbu karang tersebut di atas, maka ekosistem ini menjadi ekosistem yang sangat menarik dan menjanjikan bagi kiprah pembangunan manusia, ekosistem terumbu karang tidak hanya menjadi ekosistem yang dieksploitasi (diambil) sumber daya alamnya, tetapi juga menjadi ekosistem yang dimanfaatkan bagi berbagai kegiatan, seperti perikanan dan pariwisata.

Sayangnya, eksploitasi ekosistem terumbu karang yang dilakukan selama ini telah mengindikasikan fenomena kerusakan yang tidak hanya mengancam kemampuan ekosistem dalam menyediakan sumber daya alam, tetapi juga telah mereduksi kemampuanya dalam memitigasi bencana alam di wilayah pesisir dan pulau-pulau kecil. Dampak dari kerusakan yang muncul, antara lain hilangnya daerah pemijahan, pengasuhan dan mencari makanan bagi beragam biota laut, dan berkurangnya sumber daya ikan.

Dampak lain dari fenomena diatas adalah hilangnya fungsi-fungsi fisik dari ekosistem terumbu karang, seperti peredam gelombang, dan pencegah instrusi air laut. Fenomena ini terjadi akibat praktek-praktek pemanfaatan sumber daya alam yang destruktif dan pembangunan yang tidak berwawasan lingkungan, seperti penggalian karang, pengeboman ikan karang dan sebagainya. Selain itu kerusakan ini dapat lebih diperparah akibat adanya fenomena perubahan iklim.

Eksploitasi sumberdaya alam di wilayah pesisir dan pulau-pulau kecil secara besar-besaran tanpa mempertimbangkan kelestariannya, berdampak pada menurunnya kualitas lingkungan hidup di wilayah tersebut, termasuk terumbukarang. Menurut hasil penelitian Pusat Pengembangan Oseanologi (P20) LIPI yang dilakukan pada tahun 2000, kondisi terumbu karang Indonesia $41,78 \%$ dalam keadaan rusak, 28,30 \% dalam keadaan sedang, 23,72 \% dalam keadaan baik, dan 6,20 \% dalam keadaan sangat baik. Hal ini menunjukkan telah terjadi tekanan yang cukup besar terhadap keberadaan terumbu karang di Indonesia pada umumnya oleh berbagai ancaman dan faktor-faktor penyebab kerusakan.

Demikian juga halnya dengan Kabupaten Wakatobi, Sulawesi Tenggara. Kawasan ini juga mempunyai potensi sumber daya alam pesisir dan lautan serta jasa-jasa lingkungan khususnya terumbu karang, yang memiliki prospek perekonomian yang mampu untuk mendorong pertumbuhan dan pengembangan pemukiman dan kegiatan ekonomi serta sosial lainnya di sekitar kawasan tersebut.

Seiring dengan meningkatnya berbagai akitivitas pemanfaatan sumberdaya pesisir dan laut di kawasan 
Kabupaten Wakatobi, sebagai konsekuensi dari penangkapan ikan, pengurangan daerahpertambahan penduduk di wilayah tersebut, daerah penangkapan ikan, berkurangnya telah menimbulkan berbagai tekanan terhadap pendapatan dalam waktu tertentu, kondisi terumbu karang di kawasan tersebut. bantuan-bantuan teknis, administrasi, Penelitian tingkat Kabupaten Wakatobi telah penciptaan berbagai alternatif mata mendata terumbu karang sebanyak 36 titik pencaharian, dan lain sebagainya.

penyelamatan dengan 72 transek dari 19

Beberapa isu utama menyangkut stasiun terumbu karang di Karang Kapota, kepentingan daerah adalah: (a) Perlunya Karang Kaledupa, Pulau Kaledupa, Pulau Tomia memberdayakan masyarakat dengan dan Pulau Binongko. Dari hasil penelitian memberikan kewenangan secara khusus tersebut diperoleh kondisi terumbu karang dalam merumuskan dan merencanakan dominan dalam kondisi rusak, dengan rincian upaya-upaya pengelolaan sumberdaya yang masih sangat bagus sebesar 1,39 \%; alam. Hal ini sebenarnya telah dijamin oleh kondisi bagus 9,72 \%; kondisi sedang 31,94\%; UU No.32 tahun 2004. (b) Kewenangan dan kondisi buruk/rusak 52,78 \%.

Rusaknya terumbu karang pada masyarakat (untuk satum kewilayahan kawasan Kabupaten Wakatobi tentu akan tertentu) memiliki hak-hak eksklusif mengancam produktivitasnya sekecil apapun terhadap sumberdaya terumbu karang yang tingkat kerusakan tersebut. Pada akhirnya terdapat di wilayah tersebut. Luasan memiliki konsekuensi sosial dan ekonomi yang wilayah ini kembali mengacu pada serius bagi masyarakat lokal khususnya ketentuan-ketentuan yang ada dalam UU nelayan tradisonal yang bergantung pada No.32 tahun 2004 dan berbagai peraturan sumber daya terumbukarang. Mengingat justru pelaksanaannya. (c) Masyarakat juga mereka inilah yang seringkali hidup di bawah memiliki hak untuk mengupayakan garis kemiskinan.

pengelolaan bersama dengan pihak ketiga

Kemudian dengan diberlakukannya UU (swasta) untuk memperoleh pendapatan No.32 tahun 2004 tentang Pemerintahan yang akan dipergunakan untuk "membayar" Daerah, maka kesempatan masyarakat lokal kembali biaya-biaya yang dikeluarkan untuk memperoleh hak dalam mengelola untuk melestarikan sumberdaya tersebut sumberdaya alam yang terdapat di wilayahnya, secara berkelanjutan. Biaya-biaya ini dalam hal ini sumberdaya terumbu karang memang tetap sebagian akan ditanggung semakin besar. Namun harus disadari pula pemerintah. (d) Pemerintah maupun bahwa pengelolaan yang dilakukan oleh Pemerintah Daerah tetap tidak akan lepas masyarakat lokal selain memberikan peluang tangan karena ada beberapa hal yang tanpa juga menuntut adanya tanggung jawab dari adanya campur tangan Pemerintah akan masyarakat tersebut. Apabila masyarakat sulit untuk ditanggulangi sendiri oleh diberikan atau menuntut hak atau legitimasi masyarakat, seperti ledakan jumlah terhadap pengelolaan sumberdaya terumbu penduduk, bantuan-bantuan teknis lainnya, karang di wilayahnya, maka mereka juga harus penciptaan berbagai peluang untuk menerima dan menjalankan kewajiban atau mengurangi tekanan terhadap sumberdaya, tanggungjawabnya untuk mengelola dsb. Pemerintah tetap berkewajiban untuk sumberdaya tersebut secara berkelanjutan. menanggulangi berbagai masalah yang sulit

Kewajiban atau tanggung jawab ditangani oleh masyarakat. (Nontji, 2001) tersebut mempunyai arti bahwa masyarakat Untuk mengembalikan fungsiharus dapat turut memikul beban biaya yang fungsi serta berbagai manfaat lain dari diperlukan untuk memulihkan kembali ekosistem terumbu karang sebagaimana di sumberdaya tersebut agar tetap lestari. Biaya uraikan diatas, maka perlu upaya-upaya pengelolaan yang harus dipikul tersebut dapat pengawasan dan pengelolaan yang terpadu meliputi berbagai hal seperti; penyediaan dan berkelanjutan berbasis ekosistem. infrastruktur pengelolaan, pelaksanaan Sehubungan dengan hal tersebut diatas, penegakan hukum, pemantauan kualitas penulis kemudian terdorong untuk sumberdaya, pengurangan unit-unit melakukan penelitian mengenai peranan 
pemerintah daerah dalam mengawasi dilihat dan dikelola secara sempit kelestarian terumbu karang di Kabupaten mengabaikan kaidah keberlanjutan dan Wakatobi. keterkaitannya dengan ekosistem dan Adapun tujuan dari penelitian ini fungsi lainnya, seperti tempat ruaya ikan adalah untuk mengetahui peran pemerintah ekonomis penting yang sering bermigrasi daerah dalam mengawasi kelestarian terumbu dari suatu tempat ke tempat lain. karang di Kabupaten Wakatobi dan untuk Pengkotakan tata kelola yang bersifat mengetahui faktor pendukung dan faktor administratif dan lebih mengutamakan penghambat peran pemerintah daerah dalam keberadaan sumberdaya terumbu karang mengawasi kelestarian terumbu karang di sebagai sumber perekonomian daerah Kabupaten Wakatobi. Kemudian Manfaat dibanding memperkuat hubungan teoritis, hasil penelitian ini diharapkan dapat keterkaitannya menjadikan catatan buram menambah dan memperluas wawasan tata kelola terumbu karang dalam era keilmuan, khususnya dalam kajian ilmu desentralisasi PWP.

pemerintahan. Manfaat praktis, penelitian ini Saat ini Rancangan Perubahan dapat menjadi bahan masukan bagi pemerintah Undang-Undang tentang Pemerintahan daerah berkaitan dengan Perannya Dalam Daerah mencantumkan perlunya Mengawasi Kelestarian Terumbu karang di melakukan penarikan kewenangan Indonesia dalam lingkup Kabupaten Wakatobi. pengelolaan Pemerintah Kabupaten/Kota

\section{B. KONSEPPENGELOLAANWILAYAHPESISIR}

Pengelolaan wilayah pesisir (PWP) perubahan tersebut menyatakan memasuki babak baru dengan disyahkannya kewenangan pengelolaan sumberdaya laut UU No. 32/2004 tentang pemerintahan daerah. sepenuhnya diserahkan kepada Pemerintah UU tersebut memberikan tanggung jawab Provinsi. Kewenangan provinsi untuk pengelolaan sumberdaya pesisir kepada mengelola sumberdaya di laut paling jauh pemerintah daerah. Devolusi tanggung jawab 12 mil laut diukur dari garis pangkal ke tersebut merupakan perubahan mendasar arah laut lepas/atau keperairan kepulauan dalam hubungan hirarkis Pemerintah Pusat, (pasal 30 ayat 3) dan kewenangan Provinsi dan Kabupaten/Kota dalam nuansa kabupaten/kota atas pengelolaan kemitraan dan kebersamaan. Rentang hirarkis sumberdaya di wilayah laut sejauh dalam birokrasi dipangkas untuk lebih maksimum 4 mil laut, menurut RUU ini mendekatkan jangkauan pelayanan kepada dihilangkan.

masyarakat dan pemangku kepentingan. Sebagaimana dijelaskan lebih lanjut Keterlibatan masyarakat dan pemangku dalam penjelasan pola Rancangan kepentingan dalam proses pembuatan Perubahan Undang-Undang tentang keputusan juga dijamin oleh undang-undang. Pemerintahan Daerah : "selama satu dekade Desentralisasi pengelolaan dan tanggung jawab pelaksanaan otonomi daerah, ternyata ini telah mengukir pola pengelolaan pembagian urusan pemerintahan yang sumberdaya pesisir di Indonesia menapaki berdampak ekologis sulit untuk dibagi babak baru.

\section{KONSEPTATAKELOLATERUMBUKARANG}

khususnya antara daerah provinsi dengan daerah kabupaten/kota. Urusan pemerintahan seperti perikanan dan kelautan sering dalam praktek dibagi

Pola tata kelola terumbu karang (coral berdasarkan batas-batas administrasi governance) sebagai sebagian dari sumberdaya pemerintahan sedangkan urusan-urusan pesisir. Pola dan tata kelola terumbu karang pemerintahan tersebut pengelolaanya akan menjadi bagian dari desentralisasi dengan lebih efektif dan efisien dikelola proporsi kewenangan, berikut tanggung berdasarkan pendekatan ekologis yang jawabnya merujuk amanat UU 32/2004.

Terumbu karang dan ekosistemnya sering 
sering tidak sesuai dengan batas-batas menjadi semakin kompleks.

administrasi pemerintahan. Demikian juga halnya dalam pengelolaan laut yang berbasis 4 mil untuk kabupaten/kota dan 4 mil sampai 12 mil untuk provinsi, dalam realitas sering banyak menimbulkan permasalahan sehingga

\section{STRATEGI PENGELOLAAN TERUMBU KARANG}

Ada tiga kategori strategi umum mengganggu efektifitas penyelenggaraan yang dapat diterapkan untuk mengelola pemerintahan daerah di bidang kelautan. Untuk terumbu karang, khususnya untuk kelancaran jalannya pemerintahan daerah, mencegah kerusakan. Ketiga kategori maka kewenangan urusan pengelolaan urusan tersebut adalah: (1) memanfaatkan pemerintahan yang berdampak ekologis akan terumbu karang secara bertanggungjawab, lebih efektif diserahkan ketingkat provinsi. (2) mengendalikan kegiatan manusia, dan Namun untuk menjamin keadilan, (3) dan mengalokasikan daerah kabupaten/kota mendapatkan bagi hasil dari perlindungan laut.

pemerintahan yang dihasilkan dari Memanfaatkan terumbu karang penyelenggaraan pemerintahan tersebut. secara bertanggung jawab memberikan

Jika Rancangan Perubahan Undang- implikasi bahwa pengguna yang Undang ini disyahkan menjadi Undang-Undang dikendalikan oleh pengelola memiliki unittentunya akan membawa perubahan unit usaha. Mengendalikan kegiatan fundamental berikutnya, karena dalam manusia untuk: Mencegah kegiatan penjelasan rancangan tersebut menegaskan ekstraktif dan penambangan karang bahwa setiap peraturan perundang-undangan pembangunan ekosistem, mengelola yang merujuk UU 31/2004 untuk pembagian pengunjung atau wisatawan yang urusan, akan mengalami dampak yang cukup menikmati estetika lingkungan terumbu signifikan.

karang, dan engelola nelayan yang

Seperti halnya ekosistem alamiah menangkap ikan. Menerapkan dua jenis lainnya, ekosistem terumbu karang merupakan penegakan hukum, yaitu penegakan hukum sebuah ekosistem yang kompleks dan memiliki dengan pendekatan interpretif dan dengan keterkaitan yang tidak terpisahkan antar pendekatan konvensional.

kompenen eko-biologis di dalamnya maupun Ide dasar dari penetapan daerah dengan sistem manusia karena ekosistem perlindungan laut adalah menjaga keutuhan terumbu karang memiliki jasa yang bermanfaat habitat dan melindungi biota-biota tertentu bagi manusia (ecosystem service). Sebagai dalam rangka menjamin keutuhan siklus ilustrasi, ekosistem terumbu karang memiliki hidup sehingga habitat dan biota-biota jasa ekosistem sebagai tempat mencari makan tersebut dapat lestari. Selanjutnya, dengan (feeding ground) bagi beberapa jenis ikan siklus hidup yang utuh tersebut mereka ekonomis tinggi yang lebih dikenal sebagai ikan akan melakukan reproduksi kemudian karang seperti famili Lutjanidae yang di keturunannya tumbuh berkembang dan Indonesia dikenal sebagai ikan merah. kemudian berpindah tempat menuju Demikian juga dengan jasa non ekstraktif tempat-tempat dimana nelayan biasanya seperti jasa kenyamanan yaitu manfaat beroperasi. Perlindungan kawasan ini ekosistem terumbu karang sebagai obyek secara langsung akan menyebabkan wisata laut. Ketika unsur manfaat untuk terumbu karang terjaga dari gangguan fisik kepentingan manusia ini muncul, maka secara sehingga perubahan-perubahan yang alamiah akan ada kegiatan manusia yang terjadi didalamnya semata-mata karena berkaitan dengan ekosistem terumbu karang. dinamika atau interaksi diantara Pada konteks inilah maka kegiatan ekonomi kompenen-kompenen pembentuk berbasis terumbu karang baik yang bersumber ekosistem terumbu karang.

pada perikanan karang maupun ekowisata laut Ekosistem terumbu karang memilki menjadi semakin tinggi intensitasnya. serangkaian nilai manfaat yang tinggi yang Peningkatan kegiatan ekonomi ini menjadikan berkaitan satu sama lain. Terumbu karang pengelolaan ekosistem terumbu karang tidak saja menyediakan tempat tinggal bagi 
sejumlah besar jenis hidupan laut, terumbu diinginkan. Sementara itu, (Bohari, 1992) karang dalam kaitannya dengan ekosistem mengemukakan pengertian pengawasan pesisir lainnya merupakan sumber makanan, sebagai berikut: suatu upaya agar apa yang obat-obatan, dan produk konsumsi lainnya. telah direncanakan sebelumnya Belum lagi nilai ekonomi yang diberikannya. diwujudkan dalam waktu yang telah Dibanyak tempat di Indonesia, terutama di ditentukan serta untuk mengetahui Indonesia Timur, terumbu karang memilki nilai kelemahan-kelemahan dan kesulitanekonomi dari kegiatan pariwisata yang tinggi. kesulitan dalam pelaksanaan tadi sehingga Selain nilai yang dapat diukur secara berdasarkan pengamatan-pengamatan langsung tersebut, terumbu karang bersama- tersebut dapat diambil tindakan untuk sama ekosistem wilayah pesisir lainnya seperti memperbaikinya demi tercapainya wujud ekosistem mangrove memiliki peran penting semula.

dalam mendukung kegiatan ekonomi yang ada

(Ukas, 2004) menyebutkan tiga diwilayah pesisir. Beberapa contohnya adalah unsur pokok atau tahapan-tahapan yang terumbu karang memiliki peran penting dalam selalu terdapat dalam proses pengawasan, daur ulang unsur hara, pemurnian air dan yaitu: (1) ukuran-ukuran yang menyajikan pengendali banjir. Salah satu peran penting bentuk-bentuk yang diminta. Standar terumbu karang adalah sebagai pelindung ukuran ini bisa nyata, mungkin juga tidak wilayah pesisir terhadap topan dan badai yang nyata, umum ataupun khusus, tetapi selama merusak. seorang masih menganggap bahwa hasilnya

Adapun pengertian pengawasan kalau adalah seperti yang diharapkan. kita melihat dari asal kata dasarnya "awas" erbandingan antara hasil yang nyata maknanya mengajak agar seseorang atau dengan ukuran tadi. Evaluasi ini harus beberapa orang dalam melakukan sesuatu dilaporkan kepada khalayak ramai yang kegiatan penuh dengan kehati-hatian, sehingga dapat berbuat sesuatu akan hal ini. (3) tidak terjadi kesalahan atau kekeliruan. Kegiatan mengadakan koreksi. PengukuranKemudian diberikan awalan"pe" atau pengukuran laporan dalam suatu sisipan"ng" dengan akhiran "an", maka pengawasan tidak akan berarti tanpa terciptalah kata pengawasan dimana dalam adanya koreksi, jikalau dalam hal ini perkembangannya dalam pemikiran manusia diketahui bahwa aktifitas umum tidak dengan merumuskan yang berbeda-beda mengarah ke hasil-hasil yang diinginkan.

antara pemikiran atau pemahaman manusia

Adapun Konsep Peran menurut yang satu dengan pemahaman manusia yang kamus, kata peran didefinisikan sebagai lainnya. Perbedaan pola pemikiran dalam "the kind of action of activity proper to any memberikan rumusan tentang pengawasan person or thing; the purpose for which tentunya sangat banyak faktor sebagai something is designed or exists; role" (jenis penyebabnya antara lain sasaran kegiatan yang aktivitas dari tindakan yang dilakukan, tingkat kesulitan tentang pekerjaan, patut/sebaiknya kepada siapapun atau hal; manusia yang dihadapinya, perkembangan tujuan di mana sesuatu yang dirancang atau lingkungan sosial dan fisik yang dihadapinya ada; peranan). Misalnya, peran telinga dan lain sebagainya yang menyebakan adalah untuk mendengar, jika tidak memberikan argumentasi yang berbeda-beda. mendengar (tuli) berarti organ telinga tidak (Makmur, 2011).

\section{E. KONSEP PENGAWASAN} berperan. peran senyum adalah (untuk) menunjukkan rasa senang. jika senyum disalah-gunakan menjadi alat untuk memperdaya, itu bukanlah perannya yang

\section{Menurut pendapat Saydam yang asli.}

dikutip oleh (Kadarisman, 2012) Contoh lain: peran mata adalah mengemukakan, pengawasan merupakan untuk melihat atau memandang. Jika mata kegiatan yang dilakukan untuk mengendalikan tidak dapat melihat, berarti organ mata pelaksanaan pekerjaan yang dilakukan agar tidak berperan. Tidak berperannya mata proses pekerjaan itu sesuai dengan hasil yang tersebut banyak penyebabnya misalnya 
karena lagi sakit mata atau rabun mata dan karena itu Pemerintah sebagai salah satu bisa juga terjadi rabun mata karena cacat sejak perangkat/organ Negara mempunyai peran lahir. Tetapi oleh pemiliknya, mata dapat juga merealisasikan tujuan berbangsa dan menjadi alat untuk memberi isyarat atau bernegara. Negara adalah suatu organisasi dijadikan lambang kecantikan. Definisi peran kekuasaan yang sangat besar dan kompleks diatas dapat juga digunakan untuk menguji berupaya mengatur hubungan/interrelasi, bahasa politik dan birokrasi indonesia. Peran interaksi dan transaksi antar anggota bersifat objektif, sedangkan tugas bersifat masyarakat atau warganya dalam suatu subjektif. Jadi peran dahulu, barulah tugas. Di wilayah hukum tertentu berdasarkan dalam bahasa politik dan birokrasi indonesia kesepakatan diantara mereka, baik sering menyimpang dari perannya, ibarat mata mengenai cara pencapaian maupun tujuan ayam, perannya melihat, ditugaskan merayu yang hendak dicapai agar mereka dapat melalui lirikan dan kedipan mata. hidup secara harmonis dan bersinergi, PemerintahDaerah yang perannya sebagai sehingga dapat meningkatkan taraf hidup. wasit, berperilaku atau bertugas menjadi Kehidupan dan kesejahteraannya secara pemain di samping tugasnya sebagai wasit, adil dan damai.

maka ini sudah dapat diramalkan akan terjadi Menurut teori Montesque (trias bahwa permainan akan berakhir dengan politica), kekuasaan Negara terdiri dari: kekacauan.(Rewansyah, 2011). kekuasaan legislatif (parlemen), kekuasaan

Dalam kajian ilmu administrasi publik Eksekutif (Pemerintah), dan kekuasaan (Negara) sering rumusan tujuan dan peran yudikatif (peradilan) serta ditambah satu menjadi kata yang sinonim. namun ada kekuasaan lagi yaitu: kekuasaan auditif sejumlah pakar yang menarik perbedaan (pengawasan/ pemeriksaan) guna antara pengertian tujuan dan peran. Tujuan mengawasi penyelenggaraan Pemerintahan menegaskan adanya cita-cita, impian dan Negara. Untuk menyelenggarakan sasaran-sasaran yang hendak dicapai yang kekuasaan Negara dibentuk organ-organ sudah ditetapkan/ ditentukan terlebih dahulu. Negara. salah satu organ Negara adalah Tujuankeberadaan Negara menunjukkan lembaga Eksekutif (Pemerintah dalam arti kawasan cita-cita, yaitu kondisi ideal yang ingin sempit). menurut hemat penulis ada 5 direalisasikan oleh pendiri bangsa tersebut (lima) peran utama (main role) Eksekutif (foundingfathers). Tujuanmenjadi ide yang (Pemerintah), yaitu : (1) peran statis kalau sudah ditetapkan dan bersifat pengaturan/regulasi; (2) peran pelayanan abstrak-idiil.Sedangkan peran menunjukkan kepada masyarakat (publicservice); (3) keadaan yang bergerak, peranandan aktivitas peran pemberdayaan masyarakat usaha termasuk kondisi nyata yang terjadi. (empowering people); (4) peran Peran merupakan pelaksanaan dari tujuan yang pengelolaan asset/kekayaan Negara; (5) hendak dicapai. Peran bersifat nil dan konkrit. peran keamanan, pengamanan dan Tujuan tanpa peran adalah steril, sedangkan perlindungan. (Rewansyah, 2011).

peran tanpa tujuan adalah mustahil. Sedangkan Keikutsertaan pemerintah dalam definisi yang kedua, peran menunjukkan tujuan melestarikan terumbu karang sangat yang menjadi dasar atau alasan pengadaan/ penting. Pemerintah sebagai pengatur dan adanya (existence/eksistensi) lembaga yang pengawas masyarakat. Pemerintah dapat disebut instansi Pemerintah sebagai alat menetapkan kebijakan dan peraturanNegara untuk mencapai tujuan yang telah peraturan untuk menyelamatkan ditetapkan. pengertian ketiga, peran sama terumbu karang. Membuat rencanadengan fungsinya (function). rencana perbaikan lingkungan yang Dalam kaitannya dengan Negara, sudah rusak dan mencegah kerusakan tujuan menunjukkan apa yang secara idiil terumbu karang. Pemerintah juga dapat hendak dicapai oleh bangsa dan Negara itu, bekerja sama dengan lembaga-lembaga sedangkan peran adalah pelaksanaan dari cita- atau organisasi-organisasi lingkungan cita itu dalam kenyataannya. Peran merealisir untuk menjaga kelestarian terumbu tujuan itu dalam kenyataan hidup sehari-hari. karang. Misalnya melakukan kampanye 
kampanye lingkungan hidup, bekerjasama menghimpun data yang digunakan dalam dengan media-media atau organisasi seperti penelitian ini adalah observasi penelitian, National Geographic Indonesia, WWF yang dilakukan dengan cara melakukan Indonesia, Yayasan Reef Check Indonesia, LIPI pengamatan secara langsung di lapangan (Lembaga Ilmu Pengetahuan Indonesia) dan yang berkaitan dengan peran pemerintah Yayasan TERANGI (Terumbu Karang daerah dalam mengawasi kelestarian Indonesia) dan lainnya untuk mengawasi terumbu karang di Kabupaten Wakatobi. kelangsungan hidup terumbu karang. Baik Wawancara yang digunakan oleh peneliti mengawasi eksploitasi karena ulah manusia, adalah wawancara bebas terpimpin, artinya pertumbuhan terumbu karang yang sedang peneliti mengadakan pertemuan langsung direstorasi, dan pengawasan daerah terumbu dengan petugas pemerintah, dan karang yang terancam di Indonesia. Upaya wawancara bebas artinya peneliti bebas restorasi adalah tindakan untuk membawa mengajukan pertanyaan kepada responden ekosistem yang telah terdegradasi kembali sesuai dengan jenis pertanyaan-pertanyaan menjadi semirip mungkin dengan kondisi yang telah disiapkan sebelumnya. aslinya sedangkan tujuan utama restorasi Dokumentasi, yaitu pemanfaatan informasi terumbu karang adalah untuk peningkatan melalui dokumen-dokumen tertentu yang kualitas terumbu yang terdegradasi dalam hal dianggap mendukung.

struktur dan fungsi ekosistem. Mencakup Analisis data ialah langkah restorasi fisik dan restorasi biologi. selanjutnya untuk mengelola data dimana Restorasi fisik lebih mengutamakan data yang diperoleh, dikerjakan dan perbaikan terumbu dengan fokus pendekatan dimanfaatkan sedemikian rupa untuk teknik, dan restorasi biologis yang terfokus menyimpulkan persoalan yang diajukan untuk mengembalikan biota berikut proses dalam menyusun hasil penelitian. Teknik ekologis ke keadaan semula. (Putra, 2012:17). analisis data yang digunakan dalam Pemerintah harus benar-benar penelitian ini adalah model analisa merealisasikan upaya-upaya untuk interakif.Setelah menganalisis data, peneliti menyelamatkan terumbu karang. Pemerintah harus memastikan apakah interpretasi dan perlu bersikap tegas mengenai kerusakan temuanpenelitian akurat. Validasi temuan lingkungan yang terjadi dan berusaha dengan menurut Creswell berarti bahwa sebaik-baiknya melindungi terumbu karang penelitimenentukan keakuratan dan yang juga merupakan aset negara.

\section{F. METODE PENELITIAN}

Penelitian ini memilih lokasi di Kabupaten Wakatobi. Tipe penelitian ini adalah penelitian deskriptif kualitatif yakni suatu bentuk penelitian yang bertujuan untuk memberikan gambaran umum berbagai macam data yang dikumpul dari lapangan secara objektif, sedangkan dasar penelitiannya adalah survey yakni tujuan dari penelitian deskriptif ini adalah menggambarkan mengenai situasisituasi atau kejadian-kejadian sistematis, faktual dan akurat mengenai fakta- daerah juga menjalankan otonomi yang fakta dan sifat-sifat dari peranan pemerintah seluas-luasnya, kecuali urusan daerah dalam mengawasi kelestarian terumbu pemerintahan yang menjadi urusan karang Kabupaten Wakatobi.

Teknik penelitian merupakan salah kesejahteraan masyarakat, pelayanan satu unsur penting dalam melakukan suatu umum dan daya saing daerah. penelitian. Teknik yang digunakan dalam

kredibilitas temuan melalui beberapa strategi, antara lain: member checking, triangulasi dan auditing.

\section{G. PENELITIAN DAN PEMBAHASAN}

Peran pemerintah daerah sangat dibutuhkan instansi pemerintahan karena mempunyai tugas dan peran menyelenggarakan urusan pemerintahan, pembangunan dan kemasyarakatan serta mengatur dan mengurus sendiri urusan pemerintahan menurut asas otonomi dan pemerintahan dengan tujuan meningkatkan 
Peranan pemerintah daerah akan sangat penting apabila mereka aktif untuk mendatangi masyarakat, sering menghadiri pertemuanpertemuan, dan dalam setiap kesempatan selalu menjelaskan manfaat program pemerintahan daerah. Para pimpinan masyarakat ini aktif pula dalam mengajak warga masyarakat untuk mengelola kegiatan pemerintah daerah. Apabila masyarakat melihat bahwa seluruh aparatur pemerintahan daerah ikut serta dalam kegiatan tersebut, maka masyarakat pun akan tertarik untuk ikut serta.

Sebagai pelaksana tugas pemerintahan di Kabupaten Wakatobi, Pemerintah Daerah memiliki tugas yang penting dalam hal melindungi, mengawasi dan lain sebagainya, sebagai contoh dalam hal pengawasan kelestarian terumbu karang, pemerintah daerah memilki peran yang sangat besar dan sangat mendominasi didalam mengawasi dan melindungi terumbu karang, seperti yang di ungkapkan informan Kepala Dinas Kelautan dan Perikanan:

Pemerintah daerah adalah pihak yang paling berinisiatif, pihak yang paling punya kekuatan, punya tenaga, punya dana, sarana, jadi peran pemerintah daerah itu sangat besar bahkan mendominasi dalam pelaksanaan pelestarian terumbu karang karena pemerintah daerah yang menyelenggarakan semuanya. Mengajak orang untuk tidak merusak terumbu karang, yang melakukan patroli pengawasan itu pemerintah daerah, yang menyediakan dana itu pemerintah daerah. (Wawancara, NP)

Banyak sekali peranan yang diemban oleh pemerintah daerah dalam hal menjaga dan mengawasi serta melestarikan terumbu karang. Seperti yang disebutkan oleh Kepala Dinas Kelautan dan Perikanan yaitu sebagai berikut: pemerintah daerah yang memiliki kewenangan pengawasan, dan pemerintah daerah yang melakukan koordinasi dengan seluruh stake holder Wujud peran pemerintah daerah didalam mengawasi kelestarian terumbu karang melakukan patroli pengawasan secara terus menerus, melakukan sosialisasi dan penyuluhan, melakukan pembinaan masyarakat pelaku pengrusakan, melakukan proses hukum terhadap para pelanggar atau pengrusak terumbu karang, dan penggalangan kekuatan sosial kemasyarakatan didalam pelestarian terumbu karang" (wawancara, NP)

Peran pemerintah daerah sangat diperlukan dalam upaya pelestarian sumberdaya terumbu karang, karena disadari bahwa terumbu karang adalah termasuk sumberdaya paling penting yang ada di Kabupaten Wakatobi saat ini. seperti yang diungkapkan oleh informan Kepala Dinas Pariwisata:

Menurut kacamata kami ini adalah merupakan salah satu sumberdaya penting yang dimiliki oleh daerah ini dan semua daerah saya kira dalam melaksanakan kegiatan pembangunanya pasti selalu akan berorientasi kepada sumber daya lokal yang dimiliki dan terumbu karang itu seperti yang saya katakan tadi merupakan sumberdaya penting yang dimiliki oleh wakatobi hari ini. (Wawancara, ND)

Berdasarkan dari hasil wawancara "Peran pemerintah daerah sangat bahwa terumbu karang merupakan sumber besar dan mendominasi karena daya lokal yang dianggap paling penting pemerintah daerah yang memiliki oleh pemerintah daerah dalam pekerjaan pengawasan/pelestarian, meningkatkan pembangunan daerah di pemerintah daerah yang memiliki Kabupaten Wakatobi. Oleh karena itu, dana pengawasan, pemerintah daerah pemerintah daerah bersama elemenyang memiliki tenaga pengawasan, elemen masyarakat menjadi aktor utama 
dalam menjaga kelestarian terumbu karang dalam upaya mewujudkan visi Kabupaten Wakatobi "surga nyata bawah laut". Dengan dengan Bapak NP bahwa kelompok adanya visi Kabupaten Wakatobi mewujudkan masyarakat pengawas (POKMASWAS) "surga nyata bawah laut" tentunya menarik merupakan partisipasi masyarakat dalam perhatian banyak kalangan, bukan hanya membantu pemerintah daerah untuk masyarakat di Indonesia tetapi juga di negara- mengawasi pelestarian terumbu karang negara lain merasa tergiur untuk melakukan dengan mewujudkan tugas-tugas sebuah penelitian terutama tentang bagaimana pemerintah daerah seperti pada tahap kondisi bawah laut Wakatobi.

Dengan keadaan seperti itu tentunya perencanaan, pelaksanaan, dan evaluasi.

Menurut Kepala Dinas Kelautan harus ditopang dengan sistem pengawasan laut dan Perikanan mengatakan bahwa tahap yang lebih baik, khususnya terumbu karang perencanaan yang akan dilakukan oleh harus dijaga karena disadari bahwa menjaga pemerintah daerah yaitu:

terumbu karang adalah merupakan pintu utama kepariwisataan Wakatobi dan menjadikan Kabupaten Wakatobi lebih terkenal, Seperti yang diungkapkan oleh Staf Dinas Pariwisata:

"peran pemerintah daerah sangat besar di dalam konservasi atau dalam pelestarian terumbu karang yang ada di Kabupaten Wakatobi ini karena dimana "Pembinaan dan pembimbingan masyarakat, Dukungan sarana, dana dan peningkatan kapasitas pengawas misalnya dengan cara kita latih, kita dorong mereka. (wawancara, NP) dengan melestarikan atau menjaga bahwa pada tahap perencanaan biasanya keutuhan terumbu karang ini termasuk masyarakat dibina dan dibimbing dan pintu utama untuk sebagai diberikan penyadaran akan pentingnya kepariwisataan yang ada di Kabupaten pelestarian terumbu karang dengan tidak Wakatobi jadi dengan kekayaan yang melakukan pengrusakan seperti dimiliki alam laut Wakatobi ini itu pemboman, pembiusan, dan ilegal fishing adalah membuat Wakatobi menjadi serta adanya dukungan sarana prasarana akan semakin terkenal. (wawancara, bisa menunjang kegiatan pemerintah $\mathrm{AM})$

daerah dalam melakukan aktifitas pengawasan terumbu karang. Selanjutnya

Pemerintah daerah juga mengajak setiap individu yang ditugaskan pemerintah masyarakat supaya berpartisipasi dalam daerah dalam melakukan pengawasan menjaga dan mengawasi kelestarian terumbu tersebut senantiasa selalu meningkatkan karang. Adapun wujud partisapasi masyarakat kapasitasnya.

dalam mengawasi kelestarian terumbu karang adalah sebagai berikut seperti yang dikatakan 1. Pengawasan pada Tahap Pelaksanaan oleh Kepala Dinas Kelautan dan Perikanan:

$\begin{array}{lll}\text { Bagaimana } & \text { wujud } & \text { partisipasi } \\ \text { masyarakat } & \text { dalam } & \text { membantu }\end{array}$
Kegiatan

pemerintah daerah didalam mengawasi pemerintah daerah pada tahap kelestarian terumbu karang maka itu perencanaan, maka pada tahap pelaksanaan masyarakat membentuk diri menjadi pemerintah daerah melakukan persiapankelompok-kelompok pengawas persiapan untuk mewujudkan apa yang namanya kelompok masyarakat sudah di agendakan di tahap perencanaan. pengawas (POKMASWAS). Kemudian Adapun tahap pelaksanaan kegiatan yang mengenai tugas-tugas mereka ada yang dilakukan pemerintah daerah menurut mereka rencanakan, ada Kepala Dinas Kelautan dan Perikanan yaitu perencanaanya, ada pelaksanaanya dan sebagai berikut:

ada evaluasinya. (Wawancara, NP) 
Faktor pendukung peran Memberi mereka kewenangan pemerintah daerah dalam mengawasi terbatas kepada kelompok-kelompok kelestarian terumbu karang adalah hal-hal pengawas masyarakat itu, Dimonitor yang menunjang keberhasilan peran oleh aparat dinas kelautan dan pemerintah daerah dalam menjaga dan perikanan di wilayah-wilayah mengawasi kelestarian terumbu karang. kecamatan. (wawancara, NP)

Adapun hal-hal yang menunjang peran pemerintah daerah dalam mengawasi

Dari penjelasan tersebut dapat kelestarian terumbu karang adalah dapat disimpulkan bahwa pada tahap pelaksanaan ini dilihat dari hasil wawancara dengan Kepala pemerintah daerah memberikan kewenangan Dinas Kelautan dan Perikanan Kabupaten terbatas kepada kelompok masyarakat Wakatobi.

pengawas (POKMASWAS) ini dalam proses mengawasi kelestarian sumberdaya terumbu karang. Selain itu mereka dimonitor oleh aparat dinas kelautan dan perikanan untuk melakukan pemantauan atau mengawasi terumbu karang di wilayah-wilayah kecamatan atapun di setiap desa yang ada di Kabupaten Wakatobi.

\section{Peran Pemerintah Daerah Pada Tahap Evaluasi Kegiatan}

Setelah pada tahap pelaksanaan kegiatan, maka pemerintah daerah akan melakukan tahap evaluasi untuk membahas sejauh mana tugas aktivitas-aktivitas yang sudah dilakukan sebelumnya. Misalnya terdapat kekurangan minyak, berhasilnya mengantisipasi pelaku pemboman dan juga memberikan arahan atau penyadaran kepada masyarakat nelayan yang masih minim pengetahuan akan pentingnya kelestarian sumberdaya terumbu karang. Sebagaimana yang diungkapkan oleh Staf Kepala Dinas Kelautan dan Perikanan yaitu:

Pada tahap evaluasi ini dikaji seberapa jauh efektifitas tugas mereka dan dibuat kesimpulan-kesimpulan untuk menentukan langkah-langkah berikutnya. (Wawancara, MJ)

Berdasarkan hasil wawancara di atas peran pemerintah daerah dalam untuk mengantisipasi aktifitas-aktifitas seperti mengawasi kelestarian terumbu karang kekurangan minyak dan mengantisipasi adalah hal-hal yang menghambat kinerja pemboman dievaluasi kembali untuk membuat pemerintah daerah dalam mengawasi dan kesimpulan serta rencana-rencana untuk menjaga kelestarian sumberdaya terumbu menentukan langkah-langkah kedepannya yang karang. Ada berbagai hal yang menghambat jauh lebih baik lagi.

\section{Faktor Pendukung dan Faktor Penghambat}

Adapun hal-hal yang menunjang keberhasilan peran kami dalam kelestarian terumbu karang adalah dapat saya rincikan sebagai berikut aparatur yang diberi tugas oleh negara untuk melakukan pengawasan, Komitmen pemerintah daerah dan seluruh kompenen masyarakat karena disadari bahwa terumbu karang merupakan salah satu-satunya kekayaan alam yang ada di kabupaten wakatobi yang bisa menjadi obyek pembangunan, sebagian besar masyarakat wakatobi menyatakan dukungan yang kuat didalam pelestarian terumbu karang. Baik itu tokoh adat, tokoh masyarakat dan tokoh agama, dan dukungan pemerintah pusat, lembaga-lembaga yang konsen terhadap pelestarian sumber daya alam dunia seperti The Natural Conservacy (TNC), World Wide Foundation (WWF), United State Agency International Development (USAID) dan Bank Dunia. (Wawancara, NP)

Sementara itu faktor penghambat peran pemerintah daerah dalam mengawasi kelestarian terumbu karang sebagaimana yang dikatakan oleh Kepala menjaga dan mengawasi 
Dinas Kelautan dan Perikanan:

Tenaga aparat pengawasan yang relatif kurang dibandingkan dengan luas wilayah yang harus diawasi. (bayangkan sampai di koko sana kalau kita hanya dua orang bagaimana, Sarana prasarana yang memadai pemerintah daerah dalam mengawasi sangat terbatas dan dana yang juga kelestarian terumbu karang yaitu adanya belum cukup untuk mendukung komitmen yang kuat dari pemerintah kegiatan operasional pengawasan. daerah, seluruh kompenen masyarakat dan (Wawancara, NP) dukungan yang kuat dari pemerintah pusat serta lembaga-lembaga yang konsen

Berdasarkan hasil wawancara tersebut terhadap pelestarian sumberdaya terumbu dapat disimpulkan bahwa ternyata masih karang. Sedangkan faktor yang terdapat kekurangan-kekurangan pemerintah menghambat peran pemerintah daerah daerah dalam menjalankan fungsinya sebagai dalam mengawasi kelestarian terumbu pengawas pelestari terumbu karang yaitu karang adalah masih kurangnya tenaga kurangnya tenaga aparat pengawasan karena pengawas, sarana prasarana yang memadai membayangkan luasnya wilayah yang perlu di masih terbatas dan dana yang belum cukup awasi, kurang memadainya sarana prasarana, untuk menjalankan operasi pengawasan serta dana yang belum cukup untuk pelestarian terumbu karang. mendukung kegiatan operasional pengawasan.

\section{H. PENUTUP}

Peran pemerintah daerah dalam mengawasi kelestarian terumbu karang di Kabupaten Wakatobi adalah dengan cara kolaborasi yaitu menggandeng seluruh instansi pemerintah, baik itu lembaga hukum, stake holder, dan lembaga-lembaga lainya yang konsen terhadap pelestarian sumberdaya alam dunia khususya terumbu karang sudah terjalin dengan baik. Dimana pemerintah daerah mengajak untuk bersinergi dan bekerja sama dalam mengawasi kelestarian terumbu karang.

Peranan pemerintah daerah dalam mengawasi kelestarian terumbu karang tersebut meliputi yaitu tahap perencanaan kegiatan pemerintah daerah dalam mengawasi kelestarian terumbu karang adalah dengan melakukan pembinaan dan pembimbingan kepada masyarakat dan peningkatan kapasitas pengawas serta melakukan pelatihanpelatihan baik kepada seluruh elemen masyarakat maupun lembaga-lembaga pemerintah, tahap pelaksanaan kegiatan pemerintah daerah dalam mengawasi kelestarian terumbu karang adalah pemerintah menjaga dan mengawasi kelestarian terumbu karang dan tahap evaluasi kegiatan pemerintah

\section{DAFTAR PUSTAKA}

\section{Bohari. 1992. Pengawasan Keuangan} Negara. Jakarta: Rajawali Press.

Kadarisman. 2012. Manajemen Pengembangan Sumber Daya Manusia, Jakarta: PT. Rajagrafindo Persada.

Makmur. 2011. Jenis Pengawasan danPembangunan. Jakarta: Erlangga

Makmur. 2011. Efektifitas Kebijakan Kelembagaan Pengawasan. Bandung : PT Refika Aditama.

Nontji, Anugerah. 2001. Naskah Kebijakan Nasional Pengelolaan Terumbu Karang Di Indonesia. Jakarta : Project Management Office.

Putra, Rajawali. 2012. Makalah Terumbu Karang,putrarajawali76.blogspot.com /2012/09/makalahterumbukarang.ht ml. diakses 14 april 2012.

Rewansyah, Asmawi. 2011. Kepemimpinan dalam Pelayanan Publik, Jakarta : Penerbit CV. Yusaintanas Prima. 
Soediono, Gatot. 2008. Analisis Pengelolaan Terumbu Karang Pada Kawasan Konservasi Laut Daerah Pulau Randayan Dan Sekitarnya Kabupaten Bengkayang Provinsi Kalimantan Barat. (Tesis) Semarang : Universitas Diponegoro.

Ukas, Maman. 2004. Manajemen: Konsep, 